\title{
DETERMINANTS OF MICRO-ENTERPRISE SUCCESS THROUGH MICROFINANCE INSTITUTIONS: A CAPITAL MIX AND PREVIOUS WORK EXPERIENCE
}

\author{
Waseem Ul Hameed* \\ The Islamia University of Bahawalpur \\ Hisham Bin Mohammad \\ Universiti Utara Malaysia \\ Hanita Binti Kadir Shahar \\ Universiti Utara Malaysia
}

\begin{abstract}
The prime objective of the study is to highlight the role of the capital mix (financial capital, social capital, human capital) on women micro-enterprise success with moderating role of previous work experience. Women owned micro-enterprise success is less as compared to the male owned micro-enterprsie, particularly in Pakistan. Rate of faliure in women micro-enterpeise is more, that is the reason women community is one of the most vulnerable group worldwide. It is evident from literature that less attention has been paid to highlight the importance of three types of capital for women micro-enterprise. To adress this issue, the current study adopted quantitative research approach and based on cross-sectional research design. Primary data was collected by using 5-point Likert scale. Questionnaires were distributed among the owners of women microenterprise in Pakistan by using area cluster sampling. SmartPLS 3 was used to analyze the data. It is found that financial capital, social capital and human capital has significant positive relationship with women microenterprise success and previous work experience moderates the relationship. Hence, this study contributed by developing a unique framework for women micro-enterprise success. It will be beneficial for practitioners to enhance women micro-enterprise success rate.
\end{abstract}

Keywords: Micro-enterprise success; Previous work experience; Micro-credit; Training/skill development; Social capital.

Received: 16 January 2018

Accepted: 20 May 2020

\section{INTRODUCTION}

Microfinance has been shown to matter significantly for raising the living standards for poor people and their hopes for breaking out of poverty (Hameed, Mohammad, \& Shahar, 2018; Razzaq, Maqbool, \& Hameed, 2019). Evidence from the literature shows that microfinance gives impact not only to individual and household level (Littlefield, Morduch, \& Hashemi, 2003; Morduch,

\footnotetext{
- Corresponding author: Waseem Ul Hameed: School of Business, Management and Administrative Sciences, The Islamia University of Bahawalpur, Pakistan. Email: expert_waseem@yahoo.com. Tel.: + 923346169730.
} 
1999), but also, its impact could also be realized on a country level (Khandker, 2005; Mosley \& Hulme, 1998). Essentially, for all motives and goals, microfinance is designed to provide access to finance those who do not have or own few valuable assets that can be used as collateral against the loan or use these assets as a capital to start or maintain an existing business (Atmadja, Su \& Sharma, 2016).

Microfinance institutions has special focus on women community. This is due to the fact that women are most vulnerable community, as $70 \%$ of worldwide poverty involves women (Ahmed, 2018; Kabeer, 2012). The condition is worse in Pakistan due to gender discrimination based on values, beliefs and cultural issues. Women represent almost $48.63 \%$ of the 212 million Pakistani people (Pakistan Census, 2017), their employment-to-population ratio is only 22.1\% (Pakistan Bureau of Statistics, 2013). That is the reason the economic contribution of Pakistani women is quite low as compared to the other developed and developing countries.

Women contribute to economic development and the national Gross Domestic Product (GDP) at an incomparable level through their participation in micro-enterprises, especially in developed countries such as in the United States of America (Hammawa \& Hashim, 2016). In the United States (US), women contribute $23 \%$ to $98 \%$ to the GDP and contributed almost USD 3 trillion to the economy and employ 23 million people (Hameed et al., 2019). Women entrepreneurs contribute $50 \%$ to the annual GDP and $54.1 \%$ to the total employment in the US; $75 \%$ to the total employment with $55 \%$ to the GDP in Indonesia, and $44 \%$ to the GDP with $56 \%$ to the total employment in Malaysia through micro-enterprises (Evbuomwan, Ikpi, Okoruwa, \& Akinyosoye, 2012; Norizaton, Abdul Halim, \& Chong, 2011). As compared to these countries, Pakistani women contribute approximately $25 \%$ to $30 \%$ to the economy (Ul-Hameed, Mohammad, \& Shahar, 2018). Therefore, low women contribution in Pakistan has negative effect on the nation's economy. That is one of the reasons of low economic development in Pakistan. Therefore, this is one of the points of motivation for this study to provide a comprehensive model in promoting women microenterprise.

To overcome the above issue, microfinance institutions are working in Pakistan to facilitate women economic activities, particularly women micro-enterprises. According to the Pakistan Microfinance Review (2017), 3,533 branches of microfinance institutions are working in Pakistan. Total women borrowers are 2.7 million and this participation is increasing day by day. Therefore, a significant number of women are participating in microfinance institutions services to start or expand their economic activity. The primary goal of microfinance institutions is to alleviate poverty and empower its beneficiaries through different services like microcredit, micro saving, training, social capital, skill development programs (Al-Shami, Razali, Majid, Rozelan, \& Rashid, 2016). It is an excellent tool to alleviate poverty (Leach \& Sitaram, 2010). Microcredit has significantly improved women income as well as to increase participation in decision-making ability (Kapila, Singla \& Gupta, 2016).

Nonetheless, social capital is vital to start a business as well as to grow the enterprises (Olomola, 2002). Literature shows that training also has significant positive relationship with microenterprises (Akanji, 2006; Cheston \& Kuhn, 2002; Kuzilwa, 2005). Therefore, different studies show that microfinance services have a significant positive relationship with microenterprises. However, poor people may face negative consequences of microfinance 
interventions (CIDA 1997; Mosley \& Hulme, 2009). Ironically, few studies argue that microfinance may be harmful to its recipients (Buckley, 1997; Rahman, 1999). As microcredit shows negative consequences when poor people choose a worse place for investment (Mosley \& Hulme, 1998). Nevertheless, sometimes training may not produce good outcomes (Swain \& Varghese, 2013). Therefore, few studies show that there is a negative effect of microfinance services on microenterprises. For instance, Atmadja, Su and Sharma (2016) found a negative relationship between financial capital and enterprise performance. Thus, there is a conflict among studies whereby few studies demonstrate that microfinance has a positive impact and other studies, argue that microfinance has a negative impact. Hence, according to Baron and Kenny (1986), there is need to introduce a moderator. According to Bernard, Kevin and Khin (2016), previous work experience should be used as a moderator between microfinance services and microenterprises.

Previous work experience is a crucial factor for micro-enterprise success. Although the previous work experience is not limited to micro-enterprise success, it is also essential for all businesses. As mentioned above, the relationship between microfinance factors and micro-enterprise success is not clear. Most of the studies show positive impact of microfinance factors. However, few studies have an inconsistent relationship of microfinance factors and micro-enterprise success. (see, for example, Atmadja, Su \& Sharma, 2016; Buckley, 1997; Rahman, 1999). Because people having previous work experience could run micro-enterprise in much better manner as compared to the people having no previous work experience. Hence, people with experience could achieve success in micro-enterprise, while people with no experience could not be able to achieve success. That is the reason; there is conflict among studies regarding effect of microfinance on micro-enterprise success. Therefore, this study is one of the attempts to examine the direct and indirect effect of microfinance through moderator (Previous work experience) on micro-enterprise success to reveal whether the previous work experience enhances the relationship. Hence, both direct and indirect relationships are compared to achieve this purpose.

Additionally, suggested from literature, there is a need to study on credit, jointly with training on entrepreneurship in developing countries, as in low-income countries women lack educational level (Harrison \& Mason, 2007; Ibru, 2009; Peter, 2001; Tazul, 2007). Hence, the framework of the current study will follow the literature. In the case of microenterprise, similar to other business ventures, microcredit cannot be a sole ingredient for success. Other factors, such as social capital and human capital are also equally important (Anthony, 2005; Bradley, McMullen, Artz \& Simiyu, 2012; Leach \& Sitaram, 2002; Tundui \& Tundui, 2012). Training and skill development programs are also included in the services of microfinance institutes. These training and skill development programs enhance the human capital. A network of people which is called social capital is also equally important as other factors. The combination of diverse forms of capital is crucial for enhancing the performance of microenterprises and without the appropriate mix, business success becomes a challenge (Atmadja, Su \& Sharma, 2016). That is why, the framework of this research study consists of different forms of capital, such as financial, social and human capital provided by microfinance institutions, as shown in Figure 1. 
Figure 1: Theoretical framework

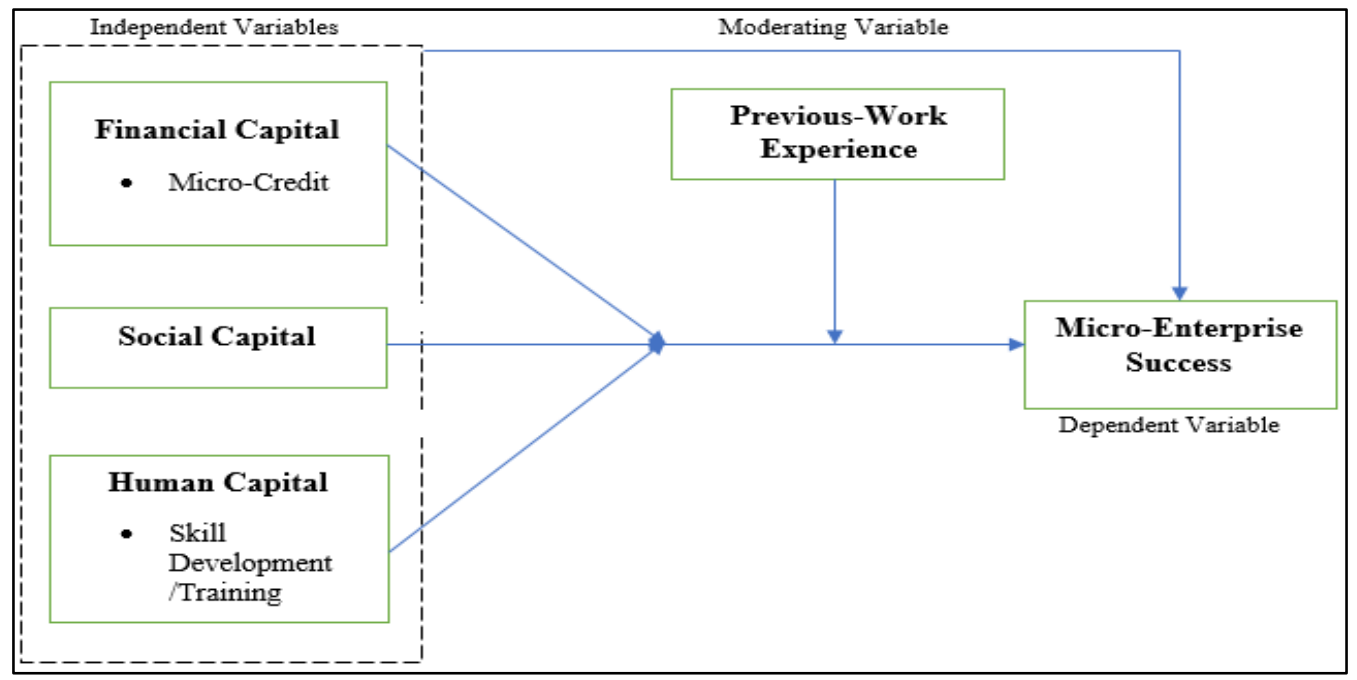

This study aims at giving an overview of the emerging research field of microfinance in a phase that is still very fluid in micro-enterprises success. Therefore, this study is one of the attempt to make things more transparent by considering the role of microfinance institutions in the field of micro-enterprises success in Pakistan, as different studies show positive impact on microenterprises success (Kevin \& Khin, 2016; Naeem, Khan, Ali, \& Hassan, 2015; Wang, 2013), but other studies found little, no impact at all and negative impact (Buckley, 1997; CIDA 1997; Mosley \& Hulme, 2009; Mosley \& Hulme, 1998; Rahman, 1999; Swain \& Varghese, 2013). Pakistan is one of the dveleoping countary has high poverty rate among women due to gender descrimination. Therefore, it is also the ultimate objective of the study to highlight the role of the capital mix on women micro-enterprise success in Pakistan, with moderating role of previous work experience.

\section{LITERATURE REVIEW AND HYPOTHESES DEVELOPMENT}

Microfinance appears to have a significant progress in making a financial resource (micro-credit) available to the bottom line of society, especially women, offering them an opportunity to make better their living standards. However, it is not necessary that microcredit itself assures better business performance; involvement of social capital and education is mandatory for business success (Atmadja, Su \& Sharma, 2016). As documented by Atmadja, Su and Sharma (2016), there is a negative relationship between financial capital and performance but a positive relationship between human capital and social capital with performance. Therefore, a mixture of financial capital (micro-credit), social capital (social network/relations) and human capital (training/skill development) is crucial to the success of microenterprise. 


\subsection{Financial Capital (Micro-Credit)}

The main aim of microfinance to reduce poverty via microcredit by facilitating business startup/expansion. Comparative to formal banking credit, microcredit from microfinance institutions is informal and heavily based on trust, without any strict collateral requirements (Atmadja, Su \& Sharma, 2016). Furthermore, as opposed to consumption, microcredit also offered to the neediest people to start up or expand existing micro-enterprise.

In developing countries, entrepreneurs manage start-up capital through external resources, predominantly as debt (Parker, 2009). Microfinance institutions facilitate entrepreneurs by providing start-up capital. Most of the people excluded from obtaining loans due to not having good credit scoring or lack of collateral requirements (Evans \& Jovanovic, 1989). Microfinance institutions facilitate these people through microcredit with minimum or no collateral requirements, such as through Self-Help Groups (SHGs) and Joint Liability Groups (JLGs). Although the borrowing cost is relatively high, microfinance institutions (MFIs) credit scheme provides a broader access to those people who cannot get bank services to handle household vulnerability and micro enterprises (Garikipati, 2008).

The initial stage of microenterprise life cycle requires financial capital, as it is the essential element to purchase fix assets, to handle working capital and for financing preliminary operations. Therefore, initial invested capital has significant positive linkage with growth as well as the venture survival (Cooper, Gimeno-Gascon, \& Woo, 1994). Thus, microcredit as the service of microfinance institutions is an essential element to start a microenterprise. Because financial capital empowers entrepreneurs to invest in fruitful activities, and to have financial cushion to defend against slow start-ups, different managerial mistakes, to defend against market downturns, exploit different business opportunities as well as speed up business growth (Bates, 1995; Cooper, Woo, \& Dunkelberg, 1988; Demirguc-Kunt, Beck, \& Honohan, 2008). Hence, microcredit is a vital force to start a microenterprise, to grow a microenterprise and to handle uncertainties. Indeed, while few studies show that microcredit increases the performance of microenterprises (Copestake, Bhalotra, \& Johnson, 2001; Leach \& Sitaram, 2002). But other studies show a question mark on the effectiveness of microcredit in successfully lifting people out from poverty and improve their welfare (Cull, Demirgüç-Kunt, \& Morduch, 2009).

Furthermore, without overlooking the significant character of microcredit in microenterprise development, Bradley et al., (2012) disclose the fact that microcredit does not always show a direct effect, but it also needs entrepreneurs' abilities for success. In the case of women, the success rate of enterprises is less. Women are less likely to have related industry-specific experience, that is why the women-owned firms are likely to have less success rate (GEM, 2010; Loscocco, Robinson, Hall, \& Allen, 1991; Watson \& Robinson, 2003). Therefore, previous work experience is crucial to build entrepreneurs' abilities and could ensure microenterprise success.

To sum up, financial capital has a positive relationship with microenterprise success, as it is an essential element to start a microenterprise. However, entrepreneurs' capabilities through previous work experience are mandatory for proper utilization of microcredit. Accordingly, it is hypothesized that:

$\mathrm{H}_{1}$ : $\quad$ Microcredit has significant positive relationship with microenterprise success 
$\mathrm{H}_{2}$ : Previous work experience moderates the relationship between microcredit and microenterprise success

\subsection{Human Capital (Training/Skill Development)}

The goal of microfinance $i$ has evolved over years to not only providing financial services but also to non-financial services (Robinson, 2001). Microfinance is a multifaceted benefactor, which contribute to the welfare of families and community (Steinwand \& Bartocha, 2008). Along with the financial services, microfinance institution is also providing non-financial services such as training and skill development programs, which is crucial to develop human capital.

Human capital refers to the formal education, attitudes, human skills and different abilities acquired through skill development programs, on-the-job training and business or industrial experiences (Atmadja, Su \& Sharma, 2016). Besides, formal education expertise is also the dimension of human capital. In the business context, it is shaped by formal as well as informal training of skills which are required to exploit opportunity (Shane, 2003).

Literature supports the fact that microfinance institutions' clients do not have specialized skills, that is why they are unable to use the services provided by microfinance in a proper way (Karnani, 2007). Therefore, an adequate training is needed on the other hand, previous work experience has a vital role in the success of enterprises, but most of the women from developing countries are lacking (Brana, 2008). Literature also shows that training has significant positive influence on the performance of enterprise (Akanji, 2006; Cheston \& Kuhn, 2002; Kuzilwa, 2005).

Entrepreneurship training is an important element which promotes entrepreneurship and affect positively on performance (Glaub \& Frese, 2011). However, there is a conflict among studies whereby according to Yunus (1999), microcredit alone is enough for poor people to lift them out from poverty and there is no need for training and skill development. On the other hand, according to Swain and Varghese (2013), training has significant positive impact on asset accumulation, although it has negative impact on income. Therefore, previous work experience moderates the relationship between training and microenterprise success which provides a better explanation of this phenomenon.

If an individual has the opportunity to acquire business experience from his family or friends, his expertise to evaluate business opportunity becomes greater (Amit, Glosten, \& Muller, 1993). Knowledge from training and previous working experience increase the effectiveness of entrepreneurs during information gathering, also offer knowledge to develop their business and helps to build confidence for opportunity exploration (Begley \& Tan, 2001; Cooper, Folta, \& Woo, 1995). It allows entrepreneurs to deal with uncertain conditions and develop abilities to exploit new combinations and innovations (Karlan \& Valdivia, 2010). Therefore, the industry-specific experience might be the critical determining factor of microenterprise success (Loscocco et al., 1991). Notably, in the case of women microenterprises, such experience tends to be the significant driver of profitability (Coleman, 2007).

Finally, from above discussion, it is concluded that trained entrepreneurs can generate better results. Hence, training has a positive link with microenterprise success. However, the role of previous 
work experience cannot be neglected, as it is vital to enhance the performance of microenterprise. Accordingly, it is hypothesized that:

$\mathrm{H}_{3}$ : $\quad$ Training has significant positive relationship with microenterprise success

$\mathrm{H}_{4}$ : $\quad$ Previous work experience moderates the relationship between training and microenterprise success

\subsection{Social Capital}

Microfinance acts not only as an economic stimulator for microenterprises but also has far-reaching social impacts. According to Coleman (1988), the concept of social capital defines as how social structure of the group can function as a source for the members of that group, and it is embedded in a structure of relations. In an enterprise context, the idea of embeddedness describing that enterprises are explained by the structures of the personal relations (Granovetter, 1985). This concept shows concrete personal relationship and network of relations in the standard economy system.

Microfinance institutions also form Self-Help Groups (SHGs) (Nasir \& Farooqi, 2016), which is a significant source of social capital. These SHGs are basically voluntary association not more than ten people (Geetha \& Babu, 2016). Therefore, social capital makes a chain of people and provide a platform in which they help each other's, which promotes microenterprises. These networks of people give access to employment opportunities, resources, psychological aid, different information and advice (Abell, Crouchley, \& Mills, 2001; Hoang \& Antoncic, 2003). And these facilities can be mobilized for entrepreneurial actions (Adler \& Kwon, 2002).

Social support mainly consists of group membership and family relationships (Allen, Markovitz, Jacobs Jr, \& Knox, 2001). According to Coleman (1988), a family forms an ideal environment for creating social capital. No doubt, family and close friends will be more involved with each other to build a network (Granovetter, 1983). In the case of women, the evidence is available from different studies that family support is one of the crucial elements for entrepreneurial success and it has a positive influence on sale, profit growth and survival of business (Bruderl \& Preisendorfer, 1998; Powell \& Eddleston, 2013). Hence, social capital is vital to the success of microenterprise. On the other hand, family members with previous work experience can be very important for social capital because these members have better knowledge to run a business. Therefore, this previous work experience has a better effect on the relationship between social capital and microenterprise success.

Nevertheless, social capital does not always have a positive impact. Sometimes it harms the business performance, in case, where the firm is a major source of household income (Cruz, Justo, $\&$ De Castro, 2012). In the case of low asset family firms, it may increase the agency cost due to not having a proper monitoring system and personal use of firm assets by family members (Dyer, 2006; Tundui \& Tundui, 2012) but previous work experience may cover these risks. As it is mentioned that previous work experience has a vital role in the success of enterprises (Brana, 2008).

Most of the businesses depend heavily on the prior knowledge and prior business experience (Simpson, Tuck \& Bellamy, 2004). According to Harada (2003), an entrepreneur's previous industrial experience, related business experience and previous market knowledge have a positive 
influence on turnover. Hence, from above literature, it is discovered that social capital has a positive association with microenterprise success and this association can be enhanced by previous work experience. Accordingly, it is hypothesized that:

$\mathrm{H}_{5}: \quad$ Social capital has significant positive relationship with microenterprise success

$\mathrm{H}_{6}$ : $\quad$ Previous work experience moderates the relationship between social capital and microenterprise success

\section{RESEARCH METHODOLOGY}

This research study is based on quantitative research approach and cross-sectional research design. This study attempted to identify the major success determinants related to microfinance institutions which affects micro-enterprises success. As the study is investigating the role of microfinance institutions on micro-enterprise success, therefore, micro-enterprise owners are selected for the target population. Lists of registered microenterprises are obtained from microfinance institutions and all micro-enterprises which are availing the services (micro credit, social capital, training/skill development) of microfinance institutions are selected. Area cluster sampling was sued, and questionnaire was distributed among the women owners of micro-enterprise in Pakistan.

Area cluster sampling is one of the most suitable technique when population is spread on a wide area (Sekaran \& Bougie, 2013; Ul-Hameed, Mohammad \& Shahar, 2018). Area cluster sampling is based on various steps which are followed in the current study. These steps are as follows;

1. Division of whole population into various clusters. In this study, Pakistan is divided into five clusters based on provinces. These clusters include; Punjab, Sindh, Balochistan, Khyber Pakhtunkhwa and Gilgit-Baltistan.

2. Clusters are selected randomly. This includes Punjab, Sindh and Khyber Pakhtunkhwa.

3. Data collection from the selected clusters. Therefore, 300 questionnaires were distributed in the selected clusters (Punjab, Sindh and Khyber Pakhtunkhwa).

In Pakistan, 3,533 branches of microfinance institutions are working. Total women borrowers are 2.7 million and this participation is increasing day by day (Pakistan Microfinance Review, 2017). Comrey and Lee (1992) provided example in a sequence for inferential statistics. According to him, sample which is less than 50 participants will have noticed to be a weaker sample; sample size of 100 participants will be weak; 200 participants will be adequate; 300 participants will be considered as good; 500 participants are considered as very good and 1000 will be outstanding. Therefore, keeping in view the above Comrey and Lee (1992) findings, the 300-sample size has selected.

Micro credit is measured based on loan size, interest rate, loan obtaining and payment procedure, and repayment period. Social capital is measured based on network of relations. Training is measured based on usefulness of training, frequency of training programs, role of training in social status, family improvement and personal attributes. All the measures are adapted from previous studies. 
According to Sekaran (2003), measurement scale is an appropriate method to understand the relationship among different variable. 5-point Likert scale was used to collect the data. The questionnaire was translated into Urdu language. This translation was confirmed with back to back translations by taking help from experts including professors from English and Urdu department. Therefore, it was confirmed that the translation is in line with English. It was further confirmed through pilot study. Three hundred (300) questionnaires were distributed among the women owners of micro-enterprise, two hundred fifteen (215) was returned, ten (10) were incomplete and excluded form study. Hence, two hundred and five (205) questionnaires were used to analyze the data.

Partial Least Square (PLS)-Structural Equation Modeling (SEM) approach is used in this study. This is one of the most prominent techniques to analyze the primary data which is recommended by various studies (Reinartz, Haenlein \& Henseler, 2009; Ringle, Wende \& Becker, 2015). Generally, it is based on two major steps, 1) measurement model assessment, 2) structural model assessment. Measurement model is based on confirmatory factor analysis (CFA) including the construct reliability and validity. Structural model is based on the relationship testing among variables. All the steps of PLS-SEM are shown in Figure 2.

Figure 2: Two-Step PLS-SEM Process

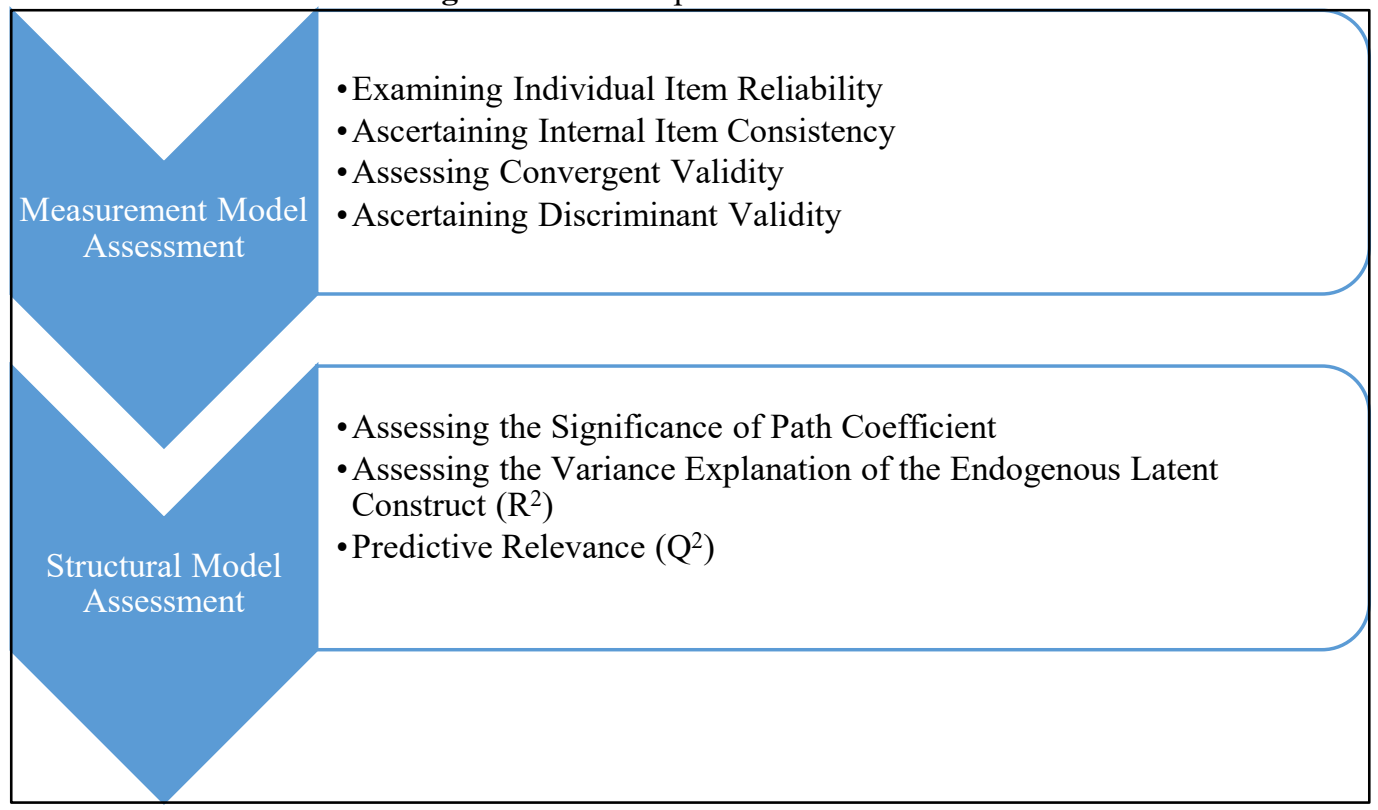

Source: Henseler, Ringle and Sinkovics (2009) 


\section{RESEARCH ANALYSIS AND RESULTS}

\subsection{Measurement Model Assessment}

As the measures are adapted from previous studies and questionnaire was translated into Urdu language, that is the reason the reliability as well as validity was assessed. For this purpose, composite reliability, factor loading, average variance extracted (AVE) and discriminant validity was examined. Smart PLS 3 was used for this purpose. It is helpful to detect weakness in instrument (Cooper \& Schindler, 2001). Figure 3 shows the factor loading of each item in the instrument.

Figure 3: Measurement Model Assessment

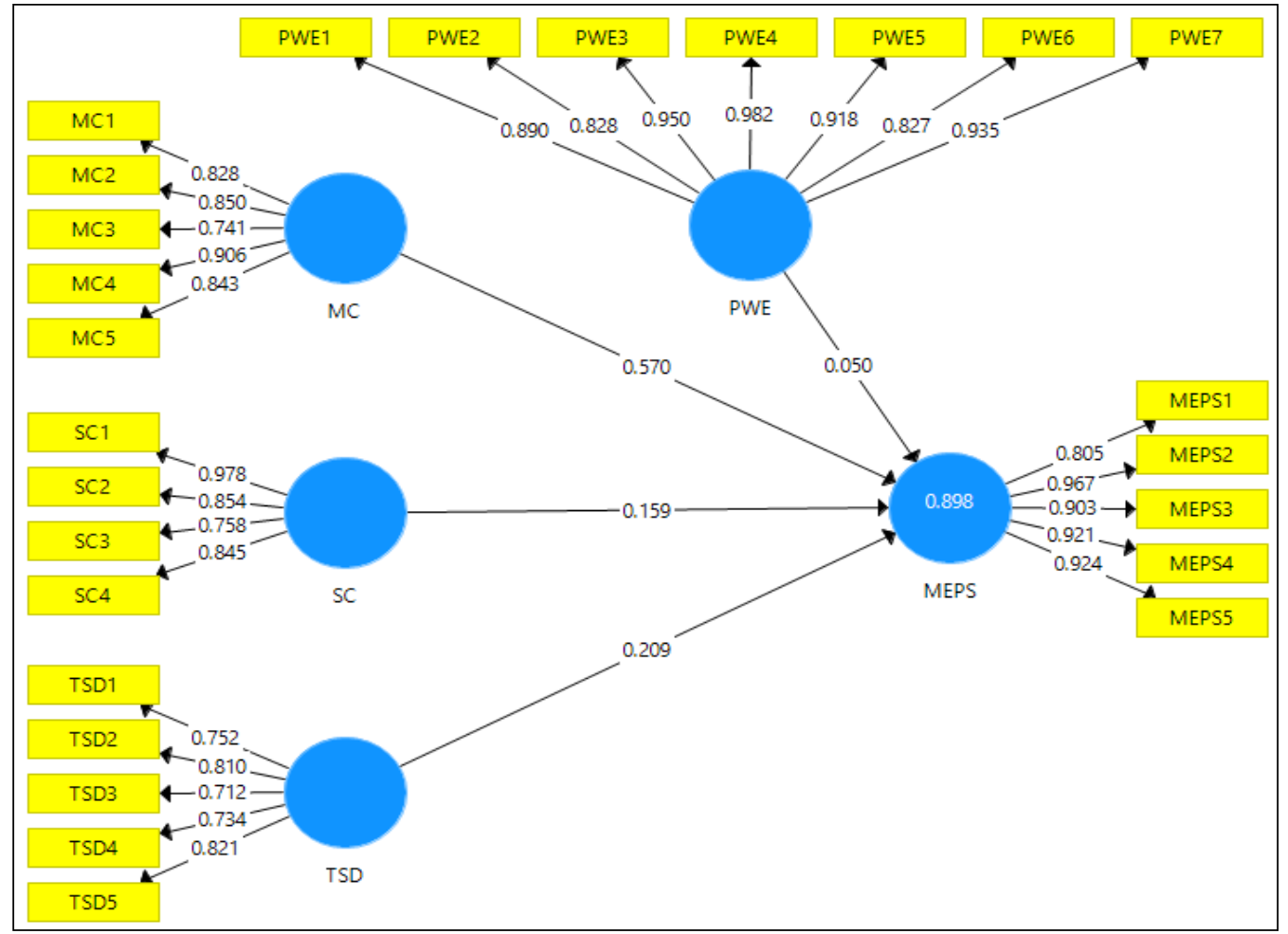

Average variance extracted (AVE) must be equal to 0.50 or above and the composite reliability must be equal or greater than 0.70 (Fornell \& Larcker, 1981; Hair \& Lukas, 2014; U1-Hameed, Mohammad, Shahar, Aljumah, \& Azizan, 2019; Ul-Hameed, Mohammad, \& Shahar, 2018). Moreover, factor loading 0.5 or above validates the convergent validity (Hair, Black, Babin, Anderson, \& Tatham, 2010). Table 1 shows the internal Consistency, convergent validity, composite reliability and average variance extracted (AVE). 
Table 1: Internal Consistency, Convergent Validity and Average Variance Extracted (AVE)

\begin{tabular}{|c|c|c|c|c|}
\hline Construct & Indicators & Loadings & $\begin{array}{l}\text { Composite } \\
\text { Reliability } \\
\end{array}$ & AVE \\
\hline \multirow{5}{*}{ Micro Credit (MC) } & $\mathrm{MC1}$ & 0.828 & & \multirow{5}{*}{0.758} \\
\hline & $\mathrm{MC} 2$ & 0.850 & & \\
\hline & MC3 & 0.741 & 0.941 & \\
\hline & MC4 & 0.906 & & \\
\hline & MC5 & 0.843 & & \\
\hline \multirow{4}{*}{ Social Capital (SC) } & SC1 & 0.978 & \multirow{4}{*}{0.946} & \multirow{4}{*}{0.807} \\
\hline & $\mathrm{SC} 2$ & 0.854 & & \\
\hline & $\mathrm{SC} 3$ & 0.758 & & \\
\hline & $\mathrm{SC} 4$ & 0.845 & & \\
\hline \multirow{5}{*}{$\begin{array}{l}\text { Training/Skill } \\
\text { development (TSD) }\end{array}$} & TSD1 & 0.752 & \multirow{5}{*}{0.910} & \multirow{5}{*}{0.662} \\
\hline & TSD2 & 0.840 & & \\
\hline & TSD3 & 0.712 & & \\
\hline & TSD4 & 0.734 & & \\
\hline & TSD5 & 0.821 & & \\
\hline \multirow{7}{*}{$\begin{array}{l}\text { Previous Work } \\
\text { Experience (PWE) }\end{array}$} & PWE1 & 0.890 & \multirow{7}{*}{0.968} & \multirow{7}{*}{0.845} \\
\hline & PWE2 & 0.828 & & \\
\hline & PWE3 & 0.950 & & \\
\hline & PWE4 & 0.982 & & \\
\hline & PWE5 & 0.918 & & \\
\hline & PWE6 & 0.827 & & \\
\hline & PWE7 & 0.935 & & \\
\hline \multirow{5}{*}{$\begin{array}{l}\text { Micro-enterprise } \\
\text { Success (MEPS) }\end{array}$} & MEPS1 & 0.805 & \multirow{5}{*}{0.9765} & \multirow{5}{*}{0.8456} \\
\hline & MEPS2 & 0.967 & & \\
\hline & MEPS3 & 0.903 & & \\
\hline & MEPS4 & 0.921 & & \\
\hline & MEPS5 & 0.924 & & \\
\hline
\end{tabular}

Table 1 show that the factor loading for each item is more than 0.7 , composite reliability is more than 0.7 and average variance extracted is also more than 0.7 . Hence, all the values are more than acceptable range. Table 2 shows the discriminant validity.

Table 2: Discriminant Validity

\begin{tabular}{lccccc}
\hline \hline & MC & MEPS & PWE & SC & TSD \\
\hline Micro Credit (MC) & 0.870 & & & & \\
Micro-enterprise Success (MEPS) & 0.860 & 0.925 & & & \\
Previous Work Experience (PWE) & 0.724 & 0.747 & 0.920 & & \\
Social Capital (SC) & 0.773 & 0.811 & 0.797 & 0.899 & \\
Training/Skill development (TSD) & 0.835 & 0.838 & 0.682 & 0.786 & 0.820 \\
\hline \hline
\end{tabular}




\section{2. $\quad$ Structural Model Assessment}

PLS structural model was used for hypotheses testing (Hameed \& Naveed, 2019; Hameed, Basheer, Iqbal, Anwar, \& Ahmad, 2018). Figure 4 shows that direct relationship of micro credit, social capital and training/skill development on micro-enterprise success. It shoes that t-value for all three relationships is more than acceptable range. The t-value for first, second and third relationship is $4.896,2.537$ and 2.130 respectively.

Figure 4: Structural Model Assessment (Direct effect)

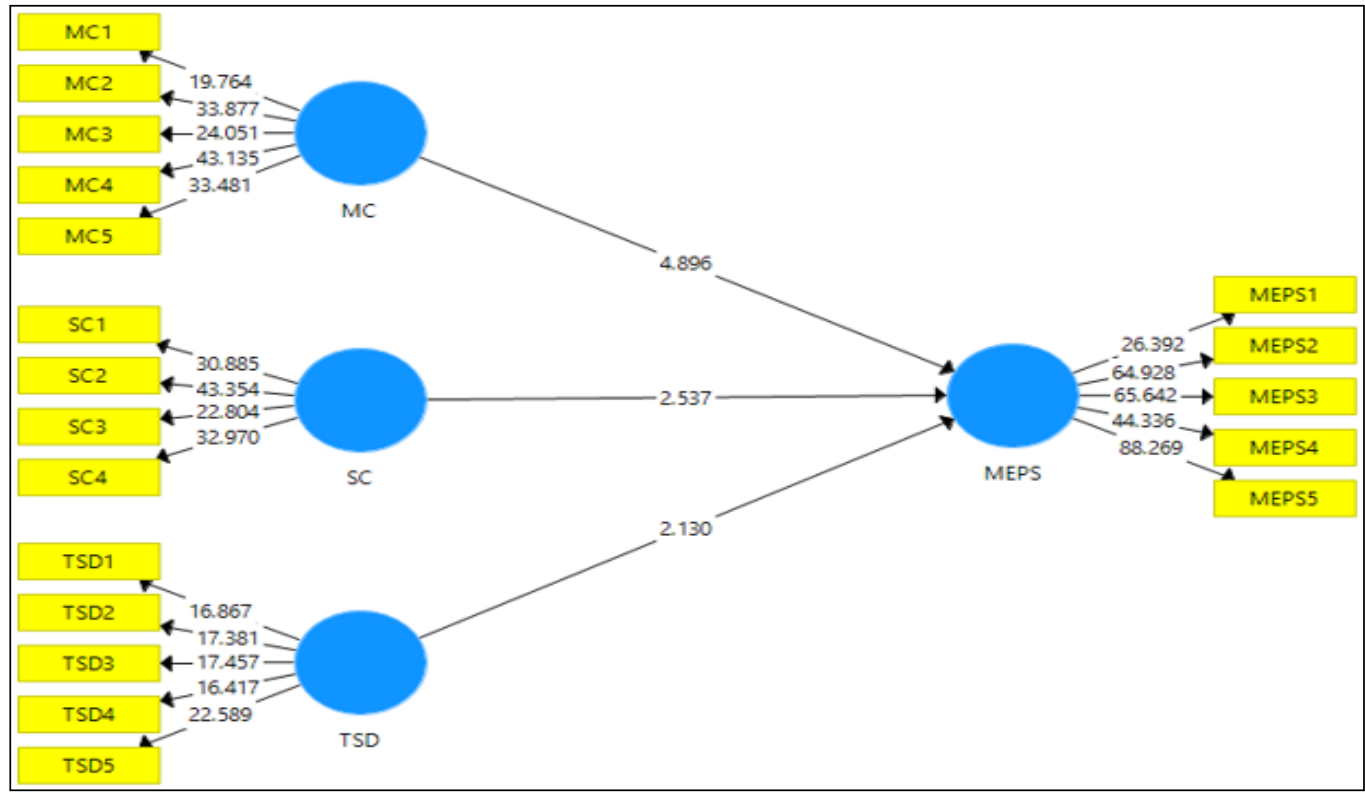

Table 3 shows that all relationships are significant, as the p-value is less than 0.05 . Moreover, for all relationship's beta value is positive, which means that all the independent variables have positive relationship with dependent variable.

Table 3: Results of structural Model Assessment (Direct effect)

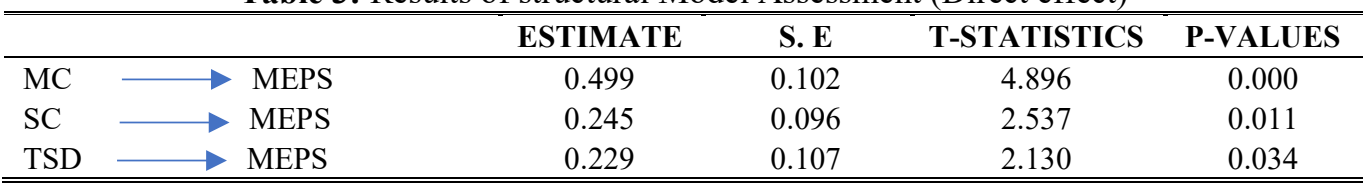

\subsubsection{Assessment of Variance Explained in the Endogenous Latent Variable}

$\mathrm{R}$-squared value of 0.60 is substantial and 0.19 is weak and 0.33 is moderate (Chin, 1998). Below Table 4 shows the R-Square value of the current study. It indicates that a set of variables are 
explained $82.9 \%$ of variance in micro-enterprise success. According to Chin (1998), this value is strong.

Table 4: Variance Explained in the Endogenous Latent Variable

\begin{tabular}{lc}
\hline \hline Latent Variable & Variance Explained $\left(\mathbf{R}^{2}\right)$ \\
\hline Micro-Enterprise Success (MEPS) & $82.9 \%$ \\
\hline \hline
\end{tabular}

\subsubsection{Assessment of Predictive Relevance $\left(Q^{2}\right)$}

By using blindfolding procedure, this study employed Stone-Geisser test for predictive relevance $\left(\mathrm{Q}^{2}\right)$ of the model (Geisser, 1974; Stone, 1974). According to Henseler and Fassott (2010), $\mathrm{Q}^{2}$ should be more than zero. Table 5 shows that $\mathrm{Q}^{2}$ is 0.658 .

Table 5: Construct Cross-Validated Redundancy

\begin{tabular}{lccc}
\hline \hline Total & SSO & SSE & $\mathbf{Q}^{2}=(\mathbf{1 - S S E} / \mathbf{S S O})$ \\
\hline $\begin{array}{l}\text { Micro-Enterprise } \\
\text { Success (MEPS) }\end{array}$ & 360.000 & 123.001 & 0.658 \\
\hline \hline
\end{tabular}

\subsection{Structural Model Assessment (Moderation effect)}

Table 6 shows the moderation effect by introducing previous work experience as moderating variable. Results shows that moderating effect is significant and beta value is positive. Therefore, it shows that previous work experience moderates the relationship.

Table 6: Results of structural Model Assessment (Moderation Effect)

\begin{tabular}{lcccc}
\hline \hline & ESTIMATE & S. E & T-STATISTICS & P-VALUES \\
\hline MC* & & & & \\
PWE $\longrightarrow$ MEPS & 0.501 & 0.098 & 5.101 & 0.000 \\
SC* $^{*}$ & & & & \\
PWE $\longrightarrow$ MEPS & 0.261 & 0.106 & 2.460 & 0.013 \\
TSD* & & & & \\
PWE $\longrightarrow$ MEPS & 0.254 & 0.099 & 2.575 & 0.010 \\
\hline \hline
\end{tabular}

\section{DISCUSSION}

In the current study, effect of three independent variables, namely, micro credit (financial capital), social capital and training/skill development (human capital) was examined on micro-enterprise success. Moreover, the moderating effect of previous work experience was examined. This study found that microfinance institution has positive role to promote women micro-enterprise. These results are in line with various previous studies (Otoo, 2012; Premchander, 2003). 
While direct analysis of three independent variables such as micro credit, social capital and training/skill development, it is found that all three variables has significant relationship with micro-enterprise success with p-values $0.000,0.011,0.034$ respectively. Moreover, it is found that beta value for all variables is positive, $0.499,0.245$ and 0.229 respectively. Thus, the results infer that micro credit, social capital and training have significant positive relationship with microenterprise success. Consistent with the current results, Afrin, Islam, and Ahmed (2010) and Kibas (2001) also found that micro-credit has significant positive effect to promote women microenterprise. Moreover, in line with current study, other studies also show that training has positive effect on women micro-enterprise (Dumas, 2001; Leach et al., 2001). Finally, social capital also has key role to increase women micro-enterprise as proved by Muniady, Mamun, Mohamad, Permarupan, and Zainol (2015). Hence, the results of the current study are consistent with the previous studies in the field of microfinance institutions and women micro-enterprise.

Furthermore, while examining the moderating effect of previous work experience, it is found that previous work experience moderates the relationship between independent variables (micro credit, social capital, training/skill development) and micro-enterprise success. It is found that p-value for three moderation effect relationships is $0.000,0.013$ and 0.010 respectively, with beta value 0.501 , 0.261 and 0.254 respectively. It indicates that previous work experience as a moderator enhances the relationship between independent variables (micro credit, social capital, training) and dependent variable (micro-enterprise success). Hence, from the results, it is concluded that all the hypothesis $\left(\mathrm{H}_{1}, \mathrm{H}_{2}, \mathrm{H}_{3}, \mathrm{H}_{4}, \mathrm{H}_{5}, \mathrm{H}_{6}\right)$ are accepted. Therefore, financial capital, social capital and human capital contributes to the micro-enterprise success.

\section{CONCLUSION}

This research study highlighted the role of capital mix (financial capital, social capital, human capital) and previous work experience on micro-enterprise success, through microfinance institution. It is found that capital mix has a major role in micro-enterprise success. Capital mix such as financial capital (micro-credit), human capital (training/skill development) and social capital (network of relations) has significant positive impact on micro-enterprise success. Unavailability of any capital affect badly on the performance of micro-enterprise success and hindered the positive role of other capitals. Furthermore, the role of previous work experience is also crucial in micro-enterprise success. It is also found that previous work experience has significant positive effect on the relationship of micro-enterprise success and capital mix. It has a positive influence to boost up the element of success. Micro credit, social capital and training/skill development increases the micro-enterprise success and previous work experience moderates the relationship. Hence, it is concluded that capital mix and previous work experience are the essential part of any micro-enterprise success. Future research is required to examine the moderating role of vulnerabilities (e g., social, economic, political, environmental) between capital mix and womenempowerment, particularly in the region of Southern Punjab Pakistan where the vulnerabilities are existing and affect negatively on micro-enterprise success. 


\section{IMPLICATIONS OF THE STUDY}

This study contributes to the body of knowledge by developing a unique framework for microenterprise success. It is vital for researchers and practitioners to adopt comprehensive capital mix as proposed in this study in order to make micro-enterprise successful. This study highlights that all three elements, namely; financial capital, human capital and social capital are essential to promote women micro-enterprise. Missing of one capital will lead to the failure of business. For instance, if the women have financial capital but she is lacking with skills (human capital) to run micro-enterprises, then micro-enterprise will remain unsuccessful. If the women have skills but lacking with financial capital, then she will not be able to run a micro-enterprise. In line with financial and human capital, network of relationship (social capital) is also equally important. Thus, this study is important for microfinance institutions and government, because it suggests that while promoting women micro-enterprise, three forms of capital known as capital mix, is important factor to provide a package of services. Missing one capital will lead to the failure of microenterprise. Consistent with capital mix, previous work experience also has importance for women micro-enterprise. In the current study, previous work experience makes clear the relationship between microfinance institutions and women micro-enterprise. As it is discussed in the introduction, there is a conflict between studies regarding the relationship of women microenterprise and microfinance institutions. Most of the studies shows positive role of microfinance institutions in women micro-enterprise development, however, few studies show negative role. This study provides the theoretical implications by making the relationship clearer that women having previous work experience are successful to run micro-enterprise and in that case microfinance institutions shows positive effect. However, in case, if the women have no previous work experience, it leads to the failure of micro-enterprise which shows negative role of microfinance institutions. Thus, previous work experience has central role in the success of women micro-enterprise. Thus, this study is also quite significant for those women who want to start running micro-enterprise. As results from this study suggests, women should be equipped with financial capital, human capital, social capital and previous work experience prior to venturing into small businesses.

\section{ACKNOWLEDGEMENTS}

We would like to acknowledge Prof. Madya Dr Mukaramah Binti Harun, Muhammad Farhan Basheer and Shazma Razzaq for providing the valuable guidelines for improving the quality of this study.

\section{REFERENCES}

Abell, P., Crouchley, R., \& Mills, C. (2001). Social capital and entrepreneurship in Great Britain. Enterprise \& Innovation Management Studies, 2(2), 119-144.

Allen, J., Markovitz, J., Jacobs Jr, D. R., \& Knox, S. S. (2001). Social support and health behavior in hostile black and white men and women in CARDIA. Psychosomatic medicine, 63(4), 609-618.

Adler, P. S., \& Kwon, S. W. (2002). Social capital: Prospects for a new concept. The Academy of Management Review, 27(1), 17-40. 
Afrin, S., Islam, N., \& Ahmed, S. (2010). Micro credit and rural women entrepreneurship development in Bangladesh: A multivariate model. Journal of Business and Management, 16(1), 1-22.

Ahmed, H. E. B. M. (2018). Impact of Microfinance on Women Empowerment, Gezira State, Sudan (2011-2015). University of Gezira.

Akanji, O. O. (2006). Microfinance as a strategy for poverty reduction. Central bank of Nigeria Economic and Financial Review, 39(4), 111-134.

Al-Shami, S. S. A., Razali, M. M., Majid, I., Rozelan, A., \& Rashid, N. (2016). The effect of microfinance on women's empowerment: Evidenc from Malaysia. Asian Journal of Women's Studies, 24(3), 324-377.

Amit, R., Glosten, L., \& Muller, E. (1993). Challenges to theory development in entrepreneurship research. Journal of Management Studies, 30(5), 815-834.

Anthony, D. (2005). Cooperation in microcredit borrowing groups: identity, sanctions, and reciprocity in the production of collective goods. American Sociological Review, 70(3), 496-515.

Atmadja, A. S., Su, J. J., \& Sharma, P. (2016). Examining the impact of microfinance on microenterprise performance (implications for women-owned microenterprises in Indonesia). International Journal of Social Economics, 43(10), 962-981.

Baron, R. M., \& Kenny, D. A. (1986). The moderator-mediator variable distinction in social psychological research: Conceptual, strategic, and statistical considerations. Journal of personality and social psychology, 51(6), 1173.

Bates, T. (1995). Self-employment entry across industry Groups. Journal of Business Venturing, 10(2), 143-156.

Begley, T. M., \& Tan, W. L. (2001). The socio-cultural environment for entrepreneurship: A comparison between East Asian and Anglo-Saxon Countries. Journal of International Business Studies, 32(3), 537-553.

Bernard, D. K., Kevin, L. L. T., \& Khin, A. A. (2016). Entrepreneurial success through microfinance services among women entrepreneurs in Sri Lanka: A pilot study and overview of the findings. International Journal of Economics and Financial Issues, 6(3).

Bradley, S. W., McMullen, J. S., Artz, K., \& Simiyu, E. M. (2012). Capital is not enough: Innovation in developing economies. Journal of Management Studies, 49(4), 684-717.

Brana, S. (2008). Microcredit in France: Does gender matter? 5th Annual Conference-Nice. European Microfinance Network.

Bruderl, J., \& Preisendorfer, P. (1998). Network Support and the Success of Newly Founded Businesses. Small Business Economics, 10(3), 213-225.

Buckley, G. (1997). Microfinance in Africa: Is it either the problem or the solution? World Development, 25(7), 1081-1093.

Cheston, S., \& Kuhn, L. (2002). Empowering women through microfinance. Draft, Opportunity International, 64.

Chin, W. W. (1998). Commentary: Issues and opinion on structural equation modeling: JSTOR.

CIDA (1997). The role of microcredit in poverty reduction and promoting gender equity: A discussion paper. Quebec: Canada International Development Agency (CIDA).

Coleman, J. S. (1988). Social capital in the creation of human capital. American Journal of Sociology, 94, 95-120.

Coleman, S. (2007). The role of human and financial capital in the profitability and growth of women-owned small firms. Journal of Small Business Management, 45(3), 303-319. 
Comrey, A. L., \& Lee, H. B. (1992). A first course in factor analysis (2nd ed.). Hillside, NJ: Erlbaum.

Cooper, A. C., Folta, T. B., \& Woo, C. (1995). Entrepreneurial information search. Journal of Business Venturing, 10(2), 107-120.

Cooper, A. C., Gimeno-Gascon, F. J., \& Woo, C. Y. (1994). Initial human and financial capital as predictors of new venture performance. Journal of Business Venturing, 9(5), 371-395.

Cooper, D. R., \& Schindler, P. S, (2001). Business Research Methods. McGraw, New York.

Cooper, A. C., Woo, C. Y., \& Dunkelberg, W. C. (1988). Entrepreneurs' Perceived Chances for Success. Journal of Business Venturing, 3(2), 97-108.

Copestake, J., Bhalotra, S., \& Johnson, S. (2001). Assessing the impact of microcredit: A Zambian case study. Journal of Development Studies, 37(4), 81-100.

Cruz, C., Justo, R., \& De Castro, J. O. (2012). Does family employment enhance MSEs performance? Journal of Business Venturing, 27(1), 62-76.

Cull, R., Demirgüç-Kunt, A., \& Morduch, J. (2009). Microfinance meets the market. The Journal of Economic Perspectives, 23(1), 167-192.

Demirguc-Kunt, A., Beck, T., \& Honohan, P. (2008). Finance for all? Policies and pitfalls in expanding Access. New York: World Bank Publications.

Dumas, C. (2001). Micro enterprise training for low-income women: The case of the community entrepreneurs Programme. The Journal of Entrepreneurship, 10(1), 17-42.

Dyer, W. G. (2006). Examining the "family effect" on firm performance. Family Business Review, 19(4), 253-273.

Evans, D. S., \& Jovanovic, B. (1989). An estimated model of entrepreneurial choice under liquidity constraints. Journal of Political Economy, 97(4), 808-827.

Evbuomwan, G. O., Ikpi, A., Okoruwa, V., \& Akinyosoye, V. (2012). Preferences of micro, small and medium scale enterprises to financial products in Nigeria. Journal of Agricultural Economics and Development, 14, 80-98.

Fornell, C., \& Larcker, D. F. (1981). Structural equation models with unobservable variables and measurement error: Algebra and statistics. Journal of Marketing Research, 18(3), 382388.

Garikipati, S. (2008). The impact of lending to women on household vulnerability and women's empowerment: Evidence from India. World Development, 36(12), 2620- 2642.

Geetha, S., \& Babu, S. (2016). Self help group: An effective approach to women empowerment in India. Asian Journal of Innovative Research, 1(2), 22-28.

Geisser, S. (1974). A predictive approach to the random effect model. Biometrika, 61(1), 101-107.

GEM. (2010). 2010 report: Women entrepreneurs worldwide: Global entrepreneurship monitor. Retrieved from http://www.gemconsortium.org/docs/download/768.

Glaub, M., \& Frese, M. (2011). A critical review of the effects of entrepreneurship training in developing countries. Enterprise Development and Microfinance, 22(4), 335-353.

Granovetter, M. (1983). The strength of weak ties: A network theory revisited. Sociological Theory, 1(1), 201-233.

Granovetter, M. (1985). Economic action and social structure: The problem of embeddedness. American Journal of Sociology, 91(3), 481-510.

Hair Jr, J. F., \& Lukas, B. (2014). Marketing research (Vol. 2). McGraw-Hill Education Australia. Hair, J. F., Black, W. C., BABIN, B. Y. A., Anderson, R., \& Tatham, R. (2010). RE [2010]: Multivariate data analysis. A Global Perspective. Ed: Pearson Prentice Hall. 
Hameed, Nisar, Q. A., Abbas, A., Waqas, A., \& Meo, S., Muhammad. (2019). Microfinance institutions as a strategic tool to enhance women's career development in Pakistan. Asian Women, 35(2), 93-128.

Hameed, W., \& Naveed, F. (2019). Coopetition-based open-innovation and innovation performance: Role of trust and dependency evidence from Malaysian high-tech SMEs. Pakistan Journal of Commerce and Social Sciences, 13(1), 209-230.

Hameed, W. U., Basheer, M. F., Iqbal, J., Anwar, A., \& Ahmad, H. K. (2018). Determinants of Firm's open innovation performance and the role of R \& D department: An empirical evidence from Malaysian SME's. Journal of Global Entrepreneurship Research, 8(1), 29.

Hameed, W., Mohammad, H., \& Shahar, H. (2018). Pursuing goal of self-sustainability but leads towards more instability: Challenges and way forward of self-help groups (SHGs). International Journal of Business and Tehnopreneurship, 8(1), 67-76.

Hammawa, Y. M., \& Hashim, N. B. (2016). women-micro entrepreneurs and sustainable economic development in Nigeria. Journal of Business and Management Volume, 18, 27-36.

Harada, N. (2003). Who succeeds as an entrepreneur? An analysis of the post-entry performance of new firms in Japan. Japan and The World Economy, 15(2), 211-222.

Harrison, R. T. \& Mason, C. M. (2007). Does gender matter? Women business angels and the supply of entrepreneurial finance. Entrepreneurship Theory and Practice, 31(3), 445-472.

Henseler, J., \& Fassott, G. (2010). Testing moderating effects in PLS path models: An illustration of available procedures. In Handbook of partial least squares (pp. 713-735). Springer Berlin Heidelberg.

Henseler, J., Ringle, C. M., \& Sinkovics, R. R. (2009). The use of partial least squares path modeling in international marketing. In New challenges to international marketing, (Advances in International Marketing, Volume 20) (pp. 277-319). Emerald Group Publishing Limited.

Hoang, H., \& Antoncic, B. (2003). Network-based research in entrepreneurship: A critical review. Journal of Business Venturing, 18(2), 165-187.

Ibru, C. (2009). Growing microfinance through new technologies. Federal University of Technology, Akure, Nigeria.

Kabeer, N. (2012). Women ${ }^{\text {ee }}$ s economic empowerment and inclusive growth: Labour markets and enterprise development. School of Oriental and African Studies, UK. IDRC. Retrieved from http://www. idrc.ca/EN/Documents/NK-WEE-Concept-Paper. pdf.

Kapila, M., Singla, A., \& Gupta, M. L. (2016). Impact of microcredit on women empowerment in india: An empirical study of Punjab state. In Proceedings of the World Congress on Engineering (Vol. 2).

Karlan, D., \& Valdivia, M. (2010). Teaching entrepreneurship: Impact of business training on microfinance clients and institutions. Review of Economics and Statistics, 93(2), 510-527.

Karnani, A. (2007). Microfinance misses its mark. Standford Social Innovation. Retrieved from http://www.ssireview.org/articles.

Khandker, S. R. (2005). Microfinance and poverty: Evidence using panel data from Bangladesh. World Bank Economic Review, 19(2), 263-286.

Kibas, P. (2001). Impact of credit on women operated micro-enterprises in Uasin Gishu district. Negotiating Social Space: East African Micro-Enterprises, 197-222. 
Kuzilwa, J. (2005). The role of credit for small business success: A study of the National Entrepreneurship Development Fund in Tanzania. The Journal of Entrepreneurship, 14(2), 131-161.

Leach, F., Abdulla, S., Appleton, H., El-Bushra, J., Cardenas, N., Kebede, K., ... \& Sitaram, S. (2001). The impact of training on women's micro-enterprise development (No. 666-201645475).

Leach, F., \& Sitaram, S. (2010). Development in practice microfinance and women's India microfinance and women's empowerment : A lesson from India. Development in Practice, (January 2012), 37-41.

Leach, F., \& Sitaram, S. (2002). Microfinance and women's empowerment: A lesson from India. Development in Practice, 12(5), 575-588.

Littlefield, E., Morduch, J., \& Hashemi, S. (2003). Is microfinance an effective strategy to reach the millennium development goals? Focus Note 24. Retrieved from http://www.mikrofinanzwiki.de/file/570/is_mf_an_effective_strategy_to_reach_the_

Loscocco, K. A., Robinson, J., Hall, R. H., \& Allen, J. K. (1991). Gender and small business success: An inquiry into women's relative disadvantage. Social Forces, 70(1), 65- 65.

Simpson, M., Tuck, N., \& Bellamy, S. (2004). Small business success factors: The role of education and training. Education+ Training, 46(8/9), 481-491.

Morduch, J. (1999). The microfinance promise. Journal of Economic Literature, 37(4), 1569-1614.

Mosley, P., \& Hulme, D. (1998). Microenterprise finance: Is there a conflict between growth and poverty alleviation? World Development, 26(5), 783-790.

Mosley, P., \& Hulme, D. (2009). Is there a conflict between growth and poverty alleviation?. Microfinance: A reader, 65.

Muniady, R. A. L., Mamun, A. A., Mohamad, M. R., Permarupan, P. Y., \& Zainol, N. R. B. (2015). The effect of cognitive and relational social capital on structural social capital and microenterprise performance. Sage Open, 5(4).

Naeem, A., Khan, S., Ali, M., \& Hassan, F. S. (2015). The impact of microfinance on women micro-enterprises; A Case Study of District Quetta, Pakistan. American International Journal of Social Science, 4(4), 19-27.

Nasir, S., and Farooqi, S., A. (2016). Impact of microfinance on women empowerment with special reference to district Aligarh (India). Middle-East Journal of Scientific Research, 24(3): 491-497, 2016.

Norizaton, N., M, Abdul Halim, H., \& Chong, C., W. (2011). Factors affecting profitabilitity of women entrepreneurs business in Malaysia. Annual Summit on Business and Entrepreneurial Studies (ASBES 2011) Proceeding.

Olomola, A. S. (2002). Social capital, microfinance group performance and poverty implications in Nigeria. Ibadan, Nigeria: Nigerian Institute of Social and Economic Research.

Otoo, B. K. (2012). Micro-credit for micro-enterprise: A study of women "petty" traders in central region, Ghana. International journal of Scientific Research In Education, 5(3), 247-259.

Pakistan Bureau of Statistics (2013). report by Pakistan bureau of statistics, government of Pakistan. Retrieved from http://www.pbs.gov.pk/.

Pakistan Census (2017). Provisional summary results of 6th population and housing census-2017. Pakistan Bureau of Statistics, Government of Pakistan. Retrieved from http://www.pbs.gov.pk/node/2047. 
Pakistan Microfinance Review (2017). Annual assessment of the industry. Pakistan Microfinance Network. Retrieved from http://microfinanceconnect.info/assets/articles/ da6af2f0f19ca541bbc04db2f158cf98.pdf 2017, 1-92.

Parker, S. C. (2009). The economics of entrepreneurship. New York: Cambridge University Press.

Peter, B. K. (2001). Impact of credit on women-operated microenterprises in UASIN GISHU district, Eldoret, Kenya. In P. O. Alila \& P. O. Pedersen (eds), (2001). Negotiating social space: East African microenterprises . Retrieved November 18, 2013, from http://books.google.com.my/book

Powell, G. N., \& Eddleston, K. A. (2013). linking family-to-business enrichment and support to entrepreneurial success: Do female and male entrepreneurs experience different outcomes? Journal of Business Venturing, 28(2), 261-280.

Premchander, S. (2003). NGOs and local MFIs-How to increase poverty reduction through women's small and micro-enterprise. Futures, 35(4), 361-378.

Rahman, A. (1999). Micro-credit initiatives for equitable and sustainable development: Who pays? World Development, 27(1), 67-82.

Reinartz, W. J., Haenlein, M., \& Henseler, J. (2009). An empirical comparison of the efficacy of covariance-based and variancebased SEM. International Journal of Research in Marketing, 26(4), 332-344.

Ringle, C. M., Wende, S., \& Becker, J. M. (2015). Smart PLS 3. Boenningstedt: Smart PLS GmbH. Retrieved from: http://www.smartpls.com

Robinson, M. S. (2001). The microfinance revolution. Washington, D.C.: World Bank.

Razzaq, S., Maqbool, N., \& Hameed, W. U. (2019). factors effecting the elasticity of micro credit demand in Southern Punjab, Pakistan. International Journal of Social Sciences and Economic Review, 1(2), 46-53.

Sekaran, U. (2003). Research method for business: A skill-building approach (4th Edition). New York, John Wiley \& Sons.

Sekaran, U., \& Bougie, R. (2013). Edisi 6. Research Methods for Business. John Wiley \& Sons.

Shane, S. (2003). A general theory of entrepreneurship: The individual-opportunity nexus. Northamton, MA: Edward Elgar Publishing, Inc.

Steinwand, D., Bartocha, D. (2008), How Microfinance Improves Lives in Sri Lanka. Sri Lankan: German Development Cooperation.

Stone, M. (1974). Cross-validatory choice and assessment of statistical predictions. Journal of The Royal Statistical Society, Series B(Methodological), 111-147.

Swain, R. B., \& Varghese, A. (2013). Delivery mechanisms and impact of microfinance training in Indian self-help groups. Journal of International Development, 25(1), 11-21.

Tazul, I. (2007). Microcredit and poverty alleviation. Hampshire, England: Ashgate Publishing Limited.

Tundui, C., \& Tundui, H. (2012). Survival, growth strategies and performance of women owned micro and small businesses in Tanzania. International Journal of Business \& Management, 7(8), 143-155.

Ul-Hameed, W., Mohammad, H., \& Shahar, H. (2018). Microfinance institute's non-financial services and women-empowerment: The role of vulnerability. Management Science Letters, 8(10), 1103-1116.

Ul-Hameed, W., Mohammad, H., Shahar, H., Aljumah, A., \& Azizan, S. (2019). The effect of integration between audit and leadership on supply chain performance: Evidence from UK based supply chain companies. Uncertain Supply Chain Management, 7(2), 311-328. 
Wang, X. (2013). The impact of microfinance on the development of small and medium enterprises: The case of Taizhou, China. The Johns Hopkins University, Baltimore, MD, USA.

Watson, J., \& Robinson, S. (2003). Adjusting for risk in comparing the performances of male- and female-controlled SMEs. Journal of Business Venturing, 18(6), 773-788.

Yunus, M. (1999). Banker to the poor. New York, NY: PublicAffairs. 